\title{
Investigating the Potential of Sunflower Species, Fermented Palm wine and Pleurotus ostreatus for Treatment of Petroleum-contaminated Soil
}

${ }^{1}$ Udeme John Dickson; ${ }^{2}$ Michael Coffey; ${ }^{1}$ Robert John George Mortimer; ${ }^{1}$ Barry Smith; ${ }^{1}$ Nicholas Ray and ${ }^{1}$ Marcello Di Bonito.

${ }^{1}$ School of Animal, Rural and Environmental Sciences, Nottingham Trent University, Brackenhurst, Southwell, Nottinghamshire NG25 0QF, United Kingdom

${ }^{2}$ Department of Chemistry \& Forensic Sciences, School of Sciences, Nottingham Trent University, Clifton, NG11 8NS, Nottingham, United Kingdom

Contact: uj.dickson@yahoo.com

\section{ABSTRACT}

Phyto- and myco-remediation have been identified as sustainable options for treatment of petroleumcontaminated soils. To appraise the benefits thereof, the potentials of 3 sunflower species, 2 palm wine types and $P$. ostreatus to treat petroleum-contaminated soils was investigated. The study involved sampling of petroleum-contaminated soils and treatment with the phyto- and myco-remediation agents for a period of 90days. Agents used for the remediation were 3 species of sunflowers (Helianthus annus-pacino gold, Helianthus sunsation \& Helianthus annus-sunny dwarf), fermented palm wine (from 2 species of palm trees -Elaeis guineensis \& Raffia africana), and oyster mushroom (Pleurotus ostreatus). The study further investigated variation in remediation efficiency among the sunflower and palm wine species, as well as different substrates and conditions for optimal application of $P$. ostreatus. The results obtained revealed up to $340 \mathrm{~g} / \mathrm{kg} \mathrm{dry}$ weight of Total petroleum hydrocarbons (TPHs) in the soils, with remediation outcomes of up to $69 \%$ by the sunflowerHelianthus annus (Pacino gold), $70 \%$ by fermented palm wine, and $85 \%$ by $P$. ostreatus. While the remediation efficiency of sunflower species was proportional to biomass, there was no significant difference in remediation efficiency of the palm wines. It was also found that substrates type and method of application has a significant impact on the remediation efficiency of $P$. ostreatus. The study further revealed available nitrate and electrical conductivity as possible useful indicators of TPHs concentration and remediation progress in soils.

Keywords: Total Petroleum Hydrocarbons, Sunflower species, Palm wine, Pleurotus ostreatus, Petroleumcontaminated soil, Soil remediation.

\section{Introduction}

Environmental issues arising from the petroleum sector are well known (Al-Nasrawi, 2012; Adenipekun et al., 2015). These can be particularly serious in remote communities and developing countries where resources for effective management are not readily available (Albert et al., 2018). Even with the current drive for greener energy sources, it will be difficult to completely obviate the need for petroleum (Gatfaoui, 2016). The scale of environmental pollution by hydrocarbons requires concerted efforts to develop techniques for its effective 
management. This is necessary to create a balance between resource utilization and environmental sustainability (Rhodes, 2014).

Phyto- and myco-remediation are promising techniques for management of petroleumcontaminated soil (Kogbara et al., 2016; Liduino et al., 2018). Yet these techniques have not been utilised commercially in many tropical regions. Dickson et al. (2019) reported that for optimal utilisation of these techniques, ideal conditions for their applications should be investigated. There are several reports on remediation potential of sunflowers (DominguezRosado et al., 2004; Diab, 2008). Sunflowers species with different biomass are also known (Rigi, 2018). However, there are no reports relating phytoremediation of sunflowers to species or biomass. To maximise the potentials of sunflower plants for clean-up of petroleum-contaminated soils, it is necessary to investigate the variation of the remediation efficiency of different species. This will help in the choice of the plant type for use in remediation projects.

Palm trees are abundant in many tropical regions such as the Niger Delta, Nigeria (Izah \& Seiyaboh, 2018). The juice of palm trees (palm wine) is used as food and ceremonial drink. The drink becomes sour and unfit for drinking if left overnight due to fermentation and is often discarded (Santiago-Urbin \& Ruiz-Teran, 2014). Palm wine consists of a consortium of microorganisms principally the yeast- Saccharomyces species (Nwaiwu et al., 2016). Consortiums of microorganisms have been used for the effective treatment of petroleumcontaminated soils (Robichaud et al., 2019). Consequently, it is needful to investigate the potential of fermented palm wine in remediation of petroleum-contaminated soil.

P. ostreatus are ubiquitous and are known agents for treatment of petroleum-contaminated soils (Stamet, 2005; Kogbara et al., 2016; Kogbara et al., 2017). Adapting these mushrooms for remediation of petroleum-contaminated soils in the tropics, will require substrates, which are abundant in such region (Mamiro and Royse, 2008). It will also require appropriate techniques for successful in situ application.

The aim of this research was to investigate the potential of some locally available sunflower species, fermented palm wine and $P$. ostreatus for treatment of petroleum-contaminated soils that can be adapted to the Niger Delta, Nigeria. The research specifically evaluates the variation of remediation efficiency of the agents with respect to their species, and application methods. This information is important in the choice of the agents among their numerous 
species. Adapting $P$. ostreatus for use in the clean-up of petroleum-contaminated soils has been problematic (Stamet, 2005; Dickson et al., 2019). The present study also seeks to develop a realistic approach and investigate a novel substrate (Palm tree which is abundant in tropical regions) for application of $P$. ostreatus in the clean-up of petroleum-contaminated soils.

The phytoremediation agents used for the study were 3 species of sunflower plants namely, Helianthus annus (Pacino gold), Helianthus sunsation, and Helianthus annus (Sunny dwarf). The mycoremediation agents were (1) fermented palm wine from 2 species of palm trees (Elaeis guineensis and Raffia africana); and (2) white rot mushroom-Pleurotus ostreatus grown on palm tree substrates. These agents are either ubiquitous or abundant in the Niger Delta region of Nigeria. Soils from a petroleum-contaminated site at Tibshelf, Derbyshire, United Kingdom (temperate soils) were used for the initial pilot study. The outcomes would be applied to petroleum-contaminated soils from a tropical region (the Niger Delta, Nigeria), to evaluate the adaptability of the methods for both temperate and tropical soils.

\section{Materials and Method}

\subsection{Sample collection}

Soil samples were collected from an oil spill site near a decommissioned British oil well at Tibshelf, Derbyshire, UK (359414N, 444927E). The soils samples include petroleumcontaminated soils collected at the immediate vicinity of the oil well, and uncontaminated (control) soil samples collected at $200 \mathrm{~m}$ uphill from the oil well. These samples were packaged, transported to the glasshouse and stored under airtight conditions (BSI ISO/DIS 18400-203; 2016). Sunflower seeds of Helianthus annus (Pacino gold), Helianthus sunsation, and Helianthus annus (Sunny dwarf) were purchased from Nicky's Nursery Ltd, Broadstairs, Kent, UK and pre-grown on Ericaceous compost for a period of 2 weeks. The Ericaceous compost was purchased from Amenity Land Solutions, Allscott Park, Shropshire, UK. Palm wine was purchased from African grocery shops in Nottingham, United Kingdom, while grain spawns of Pleurotus ostreatus were purchased from Ann Muller's Mushrooms Ltd, Aberdeenshire, UK. Palms stump of Trachycarpus fortunei was purchased from Brookfields garden centre, Mapperley, Nottingham, UK. 


\subsection{Glasshouse experiments with the petroleum-contaminated soils}

Glasshouse experiments were carried out using the methods of Ciurli et al. (2014) in the glasshouse facility at Nottingham Trent University, Brackenhurst, UK. 1.5-litre terracotta plant pots were used for the study. The pots were placed in plant trays (Grow bag standard $100 \times 40 \times 5 \mathrm{~cm}$ ) to avoid seepage. The soil samples were air dried, ground, extraneous materials removed, sieved through a $2 \mathrm{~mm}$ sieve and homogenised. $300 \mathrm{~g}$ of the homogenised soil was weighed out and placed in each 1.5-litre plant pots. Three set of glasshouse pots were prepared to consist of uncontaminated soils set, contaminated soils without amendment and contaminated soils with amendment. Cow manure was used as soil amendment and was added to the contaminated soils to provide nutrients and as a diluent. Each Pot with the amendment was prepared by the addition of cow manure to the soils in a ratio of 1:6 (50 g of cow manure compost added to $300 \mathrm{~g}$ of soils). The amendment was properly mixed with soils for homogeneity. The amended petroleum-contaminated soils was used for growing sunflowers, treatment with fermented palm wine as well as the white rot mushrooms P. ostreatus (Table 1). All glasshouse setups were carried out in triplicates for a period of 3 months (90 days).

Table 1: Glasshouse set ups for remediation of petroleum contaminated soils from Tibshelf, UK using sunflower species, palm wine and $P$. ostreatus

\begin{tabular}{|c|c|c|c|c|c|c|c|}
\hline Samples & $\begin{array}{ll}\text { No of } \\
\text { samples }\end{array}$ & $\begin{array}{l}\text { Soil } \\
\text { Quantity }\end{array}$ & $\begin{array}{l}\text { Cow } \\
\text { manure }\end{array}$ & Sunflower & Palm wine & $\begin{array}{l}\text { Mushroom } \\
\text { Substrate }\end{array}$ & $\begin{array}{l}\text { Mushroom } \\
\text { Spawn }\end{array}$ \\
\hline $\begin{array}{lll}\text { Set1: } & \text { (Control } & \text { 1) } \\
\text { uncontaminated soil }\end{array}$ & 9 & $300.00 \mathrm{~g}$ & - & - & - & - & - \\
\hline $\begin{array}{l}\text { Set 2: (control 2) contaminated } \\
\text { soil without amendment }\end{array}$ & 9 & $300.00 \mathrm{~g}$ & - & - & - & - & - \\
\hline $\begin{array}{l}\text { Set3: (control 3) contaminated } \\
\text { soil with amendment }\end{array}$ & 9 & $300.00 \mathrm{~g}$ & $50.00 \mathrm{~g}$ & - & - & - & - \\
\hline $\begin{array}{l}\text { Set } 4 \text { : } \\
\text { contaminated soil + Sunflower }\end{array}$ & 9 & $300.00 \mathrm{~g}$ & $50.00 \mathrm{~g}$ & 1 seedling & - & - & - \\
\hline $\begin{array}{l}\text { Set } 5 \text { : } \\
\text { contaminated soil + Palm wine }\end{array}$ & 9 & $300.00 \mathrm{~g}$ & $50.00 \mathrm{~g}$ & - & 0.201 & - & - \\
\hline $\begin{array}{l}\text { Set 6: } \\
\text { contaminated soil } \quad+P . \\
\text { ostreatus }\end{array}$ & 9 & $300.00 \mathrm{~g}$ & $50.00 \mathrm{~g}$ & - & - & $20.00 \mathrm{~g}$ & $10.00 \mathrm{~g}$ \\
\hline
\end{tabular}

\subsection{Physicochemical properties of the soils}

Physicochemical properties of the soils such as particle size analysis, temperature, $\mathrm{pH}$, electrical conductivity and available nitrate were monitored at the start of the glasshouse experiments and the end of the 90 days treatment period. Soil particle compositions was determined using a laser diffraction system - Beckman LS 13320 laser diffraction particle size analyser. Temperature, $\mathrm{pH}$ and electrical conductivity were determined in situ with soil 
conductivity meter model HI-98129 (Liebig et al., 1996; Scoggins \& van lersel, 2006). Available nitrate was measured with a Horiba - LAQUAtwin NO3-11 - NO3-11C - NO3-11S Compact portable nitrate meter (Hampton et al., 2019).

\subsection{Glasshouse experiments with sunflowers}

Sunflower seedlings of Helianthus annus (Pacino gold), Helianthus sunsation and Helianthus annus (sunny dwarf) were first pre-grown on the Ericaceous compost for a period of 2 weeks. The 2 weeks old seedlings were then transplanted to the experimental pots containing the amended petroleum-contaminated soils in the glasshouse (section 2.2). A control set of sunflower plants were also grown on compost. Soil moisture content was maintained by watering of the containing trays and uptake by capillary rise, and also by vertical spraying every 4 days.

\subsection{Glasshouse experiments with fermented palm wines}

Two of the dominant species of palm trees in the Niger Delta, Nigeria from which palm wine is tapped are E. guineensis and $R$. africana. The remediation efficiency of palm wine from these two species of palm trees on petroleum-contaminated soils was therefore investigated. The palm wines were left in the open overnight (12-18 hours) to ferment (Santiago-Urbina \& Ruíz-Terán, 2014). Specified volumes of the fermented palm wines (200 $\mathrm{ml}$ ) were measured out and added to glasshouse pots containing the amended petroleumcontaminated soils (Table 1). A further $200 \mathrm{ml}$ of each freshly prepared fermented palm wines were added to the pots each week. The use of the 2 species of palm wine was to evaluate any variability in their remediation efficiency.

\subsection{Glasshouse set with P. ostreatus}

Two set of experiments were carried out with $P$. ostreatus. First, was an investigation for substrates for growing white rot mushroom under unsterilized conditions. This was followed by assessing the effect of different application procedures on the remediation efficiency of P. ostreatus on the petroleum-contaminated soils.

For the first part, 6 substrates (Table 2) were investigated for growing $P$. ostreatus under sterilised and unsterilized conditions. Based on the outcomes, Palm substrates of Trachycarpus fortunei was selected for the study. The palm substrates were prepared by maceration of plant parts (stems, roots, branches) and air drying for one week. These parts 
were further pulverized to sawdust form after air drying and used as substrate for growing P. ostreatus.

Table 2: Growth of $P$. ostreatus under sterilised and unsterilized conditions using different substrates. Estimated lignin content of substrates are also given.

\begin{tabular}{|c|c|c|c|c|c|}
\hline \multirow[b]{2}{*}{$S / N$} & \multirow[b]{2}{*}{ Substrate Type } & \multicolumn{2}{|c|}{$\begin{array}{l}\text { Time Taken for mushrooms to } \\
\text { germinate and produce fruity body } \\
\text { (weeks) }\end{array}$} & \multicolumn{2}{|c|}{ Temperature of growth $=10-15^{\circ} \mathrm{C}$} \\
\hline & & Without sterilisation & $\begin{array}{l}\text { With } \\
\text { sterilisation }\end{array}$ & $\begin{array}{l}\text { Extent of } \\
\text { germination of } \\
\text { mushroom } \\
\text { mycelia }\end{array}$ & $\begin{array}{l}\text { Estimated lignin } \\
\text { content of substrates }\end{array}$ \\
\hline 1 & Cassava peels & 6 & 3-4 & Very extensive & 8 \% (Daud et al., 2014) \\
\hline 2 & Pine barks & 3-4 & 2 & Very extensive & 53\% (OLÁR et al., 1998) \\
\hline 3 & Palm tree & 3-4 & 2 & Very extensive & $\begin{array}{l}33 \% \text { (Abdul Khalil et al., } \\
2006)\end{array}$ \\
\hline 4 & Maize cob & 8 & 3-4 & Very extensive & $\begin{array}{l}\text { 16-18\% (Wang et } \\
\text { al.,2011) }\end{array}$ \\
\hline 5 & Saw dust & 8 & 4 & Extensive & $\begin{array}{l}\text { Varies according to } \\
\text { wood type (Joshua, } \\
\text { 2016). }\end{array}$ \\
\hline 6 & Hay & 8 & 4 & Extensive & $\begin{array}{l}7 \text { and } 8 \% \text { (Whitehead \& } \\
\text { Quicke, 1964). }\end{array}$ \\
\hline
\end{tabular}

For assessing the effects of application procedures, 3 subsets were created. Firstly, mushroom spawns (10 g) were applied directly on petroleum-contaminated soils by mixing without the substrates. Secondly, mushrooms spawns (10 g) were applied on the substrates (20 g) layered on top of the contaminated soils (Adenikpekun and Fasisdi, 2005). Lastly, part of the substrates and spawns was mixed with the contaminated soils, with some parts also layered on top of the soils. This last set were prepared as follows: The substrates (10 g) were mixed with the amended soils. The mushroom spawn $(5 \mathrm{~g})$ were then added by uniformly spreading into the soils. This was then followed by layering of another $10 \mathrm{~g}$ of substrates on top of these soils. The layered substrates were also inoculated with $5 \mathrm{~g}$ of mushroom spawns.

\subsection{Sample collection, preparation and analysis}

After glasshouse set up, composite soil samples were collected at the start of the study (Time $=0$ days $)$ and after a 3-month treatment period (Time $=90$ days). Samples were airdried, sieved through a $2 \mathrm{~mm}$ mesh and extraneous materials removed, ground and homogenised prior to laboratory treatment and analysis according to methods of BS ISO 11464 (2014). Extraction of TPHs in samples was carried out using a microwave assisted extraction with a Milestone MA182-001 ETHOS UP Microwave system, using a 1:1 acetoneheptane (USEPA METHOD 3546; Punt et al., 1999). Commercial TPHs diesel range standard was used for quantification of TPHs. Sample extracts, and the TPHs standards were all 
analysed in a GC-MS (model Agilent Technologies 7000 GC/MS Triple Quad with 7890 GC and 7693 Autosampler( (USEPA 8270E).

Quantification of TPHs in the soils was carried out using the methods of BS EN ISO 16703 (2011). Initial calibration of the instruments, followed by evaluation of the concentration of TPHs, alongside calibration verification were carried out.

\subsection{Data treatment and validity}

Values for Total petroleum hydrocarbons (TPHs) are expressed in g/Kg dry weight of soils. Each sample was extracted and analysed in triplicate and the values were reported as mean

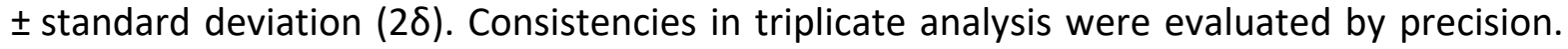
Accuracy in analysis was evaluated by calibration verification run in each set of sample analysis.

T-test was used to evaluate if differences in TPHs at different treatment times ( $T=0$ days and $\mathrm{T}=90$ day) with the same sample treatment method was significant (Zheng et al., 2019). Analysis of variance (ANOVA) were carried to evaluate variability in TPHs content among soils samples from different sampling points, glasshouse pot and the different remediation treatment sets.

\section{Results}

\subsection{Physicochemical properties of the soils}

Particle size analysis of the soil samples revealed higher clay contents (50\%), followed by silt (30\%) and sand particles (20\%) in control soils from Tibshelf, Derbyshire. For the petroleumcontaminated soils, the percentage composition was 65, 25 and 10 for clay, silt and sand particles, respectively. Levels of clay particles were higher in petroleum-contaminated soils than those of controls.

Soil $\mathrm{pH}$ was significantly affected $(\mathrm{p}<0.05)$ by petroleum contamination (Table 3$)$. The $\mathrm{pH}$ of control soil samples was near neutral (7.35-7.55) and were not significantly different during the study. The $\mathrm{pH}$ of untreated petroleum-contaminated soil samples was acidic (pH $6.53-$ $6.58)$ and were significantly different $(p=0.000$ at $T=0,0.002$ at $T=3)$ from those of uncontaminated soils. The $\mathrm{pH}$ of cow manure was in the range of 9.42-9.49. The addition of cow manure to the petroleum-contaminated soils increased soil pH from acidity to alkalinity (Table 3). The $\mathrm{pH}$ values were maintained at slightly alkaline levels $(8.50-8.90)$ throughout 
the duration of the remediation. $\mathrm{pH}$ in soils treated with cow manure were not statistically different $(p>0.05)$ during the treatment period.

A significant decrease in available nitrate was observed in untreated petroleumcontaminated soils compared to controls (Table 3). The addition of cow manure significantly increased $(p<0.05)$ levels of available nitrate in the soils (Table 3 ). Levels of available nitrate also increased as remediation progressed and correlated positively with \% decrease in the soils' TPHs (Figure 1). A Similar trend was also observed for electrical conductivity. Electrical conductivity values increased as remediation progressed and correlated positively with \% decrease in TPHs (Figure 2). Variation in temperature values $\left(19-23^{\circ} \mathrm{C}\right.$ ) was also observed during the treatment but no trend could be deduced for temperature.

\subsection{TPHs levels in the soils}

Initial concentrations of TPHs in glasshouse pots varied from 130 to $340 \mathrm{~g}$ of TPHs/Kg dry weight of soil with the highest $(340 \mathrm{~g} / \mathrm{Kg}$ ) observed in pots of untreated soils. Variations were also observed among the treatment sets such as those of sunflower species, palm wine and those treated with P. ostreatus (Figure 3). For the set involving the three-sunflower species, initial TPHs concentrations were $200 \mathrm{~g} / \mathrm{Kg}$ for $\mathrm{H}$. annus-sunny dwarf, $250 \mathrm{~g} / \mathrm{Kg}$ for $\mathrm{H}$. sunsation and $150 \mathrm{~g} / \mathrm{kg}$ for $H$. annus-pacino gold. Glasshouse pots treated with fermented palm wine from E. guineensis had initial TPHs levels of $340 \mathrm{~g} / \mathrm{Kg}$ while that of $R$. africana was $280 \mathrm{~g} / \mathrm{Kg}$ dry soil. Levels of TPHs in the soils treated with P. ostreatus at time $=0$ days were 290, 130, and $210 \mathrm{~g} / \mathrm{Kg}$ dry soils for $P$. ostreatus applied without substrates, applied by layering substrates on topsoil and that applied by a combination of mixing substrate with soil and layering.

After the 90 days remediation treatments, TPHs levels decreased to $290,90,120$ and $50 \mathrm{~g} / \mathrm{Kg}$ dry soil for untreated soils and those treated with $H$. annus-sunny dwarf, $H$. sunsation and $H$. annus-pacino gold. For the set treated with palm wine TPHs levels were 100 for E. guineensis and $90 \mathrm{~g} / \mathrm{Kg}$ for $R$. africana. Treatments with $P$. ostreatus resulted in 210, 60 and $30 \mathrm{~g}$ of TPHs per Kg dry soil for the applications without substrates, layering substrates on topsoil and those by a combination of mixing substrate with soil and layering, respectively. 
Table 3: Variation in Physicochemical properties of petroleum contaminated soils and controls from Tibshelf, UK during Glasshouse remediation treatment with sunflower species, fermented palm wine and $P$. ostreatus. Values are given as average of triplicates with standard error (S.E) +

\begin{tabular}{|c|c|c|c|c|c|c|c|c|c|c|c|c|c|c|c|c|}
\hline \multirow[t]{2}{*}{ Samples/Treatment } & \multicolumn{4}{|c|}{ Temperature ${ }^{\circ} \mathrm{C}$} & \multicolumn{4}{|c|}{$\mathrm{pH}$} & \multicolumn{4}{|c|}{ Electrical conductivity } & \multicolumn{4}{|c|}{ Available Nitrates (ppm) } \\
\hline & $\mathrm{T}=0$ & S.E & $\mathrm{T}=3$ & SE & $T=0$ & S.E & $T=3$ & SE & $T=0$ & S.E & $T=3$ & SE & $\mathrm{T}=\mathbf{0}$ & S.E & $\mathrm{T}=3$ & SE \\
\hline $\begin{array}{l}\text { Uncontaminated soil } \\
\text { samples }\end{array}$ & 20.43 & 0.17 & 22.80 & 0.14 & 7.35 & 0.04 & 7.55 & 0.05 & 7.35 & 0.03 & 1.03 & 0.03 & 621.3 & 5.21 & 610.0 & 4.96 \\
\hline Cow manure & 18.83 & 0.18 & 21.20 & 0.47 & 9.42 & 0.04 & 9.49 & 0.08 & 9.42 & 0.02 & 3.24 & 0.02 & 700.3 & 4.95 & 700.0 & 3.77 \\
\hline $\begin{array}{l}\text { Untreated petroleum- } \\
\text { contaminated soil without } \\
\text { amendment (Control 1) }\end{array}$ & 21.75 & 0.13 & 21.74 & 0.30 & 6.40 & 0.02 & 6.44 & 0.11 & 6.40 & 0.01 & 0.23 & 0.01 & 33.33 & 0.27 & 36.00 & 0.47 \\
\hline $\begin{array}{l}\text { Untreated petroleum- } \\
\text { contaminated soil + } \\
\text { amendment (Control 2) }\end{array}$ & 21.17 & 0.01 & 22.43 & 0.44 & 8.54 & 0.06 & 8.70 & 0.05 & 8.54 & 0.05 & 2.85 & 0.08 & 436.7 & 2.72 & 469.0 & 4.78 \\
\hline $\begin{array}{l}\text { Petroleum-contaminated } \\
\text { soil + Helianthus annus }\end{array}$ & 20.60 & 0.25 & 22.67 & 0.28 & 8.61 & 0.11 & 8.53 & 0.03 & 8.61 & 0.04 & 2.68 & 0.01 & 486.7 & 2.72 & 793.3 & 2.72 \\
\hline $\begin{array}{l}\text { Petroleum-contaminated } \\
\text { soil + Helianthus sunsation }\end{array}$ & 20.85 & 0.12 & 21.96 & 0.04 & 8.63 & 0.11 & 8.70 & 0.07 & 8.63 & 0.05 & 2.81 & 0.03 & 486.0 & 2.49 & 756.7 & 15.15 \\
\hline $\begin{array}{l}\text { Petroleum-contaminated } \\
\text { soil + Helianthus annus } \\
\text { (sunny dwarf) }\end{array}$ & 19.50 & 0.25 & 20.70 & 0.74 & 8.65 & 0.19 & 8.90 & 0.00 & 8.65 & 0.04 & 3.07 & 0.05 & 465.0 & 4.08 & 910.0 & 4.71 \\
\hline $\begin{array}{l}\text { Petroleum-contaminated } \\
\text { soil }+ \text { fermented palm } \\
\text { wine from Elaeis } \\
\text { guineensis }\end{array}$ & 21.00 & 0.00 & 20.80 & 0.66 & 8.82 & 0.02 & 8.90 & 0.02 & 8.82 & 0.08 & 3.47 & 0.05 & 416.7 & 17.84 & 903.3 & 2.72 \\
\hline $\begin{array}{l}\text { Petroleum-contaminated } \\
\text { soil }+ \text { fermented palm } \\
\text { wine from Raffia Africana }\end{array}$ & 20.57 & 0.46 & 20.84 & 0.36 & 8.55 & 0.15 & 8.89 & 0.01 & 8.55 & 0.05 & 3.80 & 0.08 & 393.3 & 5.44 & 873.3 & 5.44 \\
\hline $\begin{array}{l}\text { Petroleum-contaminated } \\
\text { soil + P. ostreatus without } \\
\text { substrates }\end{array}$ & 20.60 & 0.17 & 21.00 & 0.47 & 8.57 & 0.01 & 8.60 & 0.00 & 8.57 & 0.07 & 2.77 & 0.03 & 440.0 & 4.71 & 483.3 & 2.72 \\
\hline $\begin{array}{l}\text { Petroleum-contaminated } \\
\text { soil }+P \text {. ostreatus }+ \\
\text { substrates layered on soil }\end{array}$ & 21.03 & 0.03 & 20.30 & 0.09 & 8.55 & 0.13 & 8.90 & 0.00 & 8.55 & 0.00 & 3.00 & 0.00 & 430.0 & 0.00 & 720.0 & 0.00 \\
\hline $\begin{array}{l}\text { Petroleum-contaminated } \\
\text { soil }+P \text {. ostreatus }+ \\
\text { substrates mixed with } \\
\text { soils and layered }\end{array}$ & 21.01 & 0.08 & 20.60 & 0.33 & 8.79 & 0.04 & 8.73 & 0.12 & 8.79 & 0.02 & 3.83 & 0.03 & 483.3 & 11.86 & 973.3 & 5.44 \\
\hline
\end{tabular}




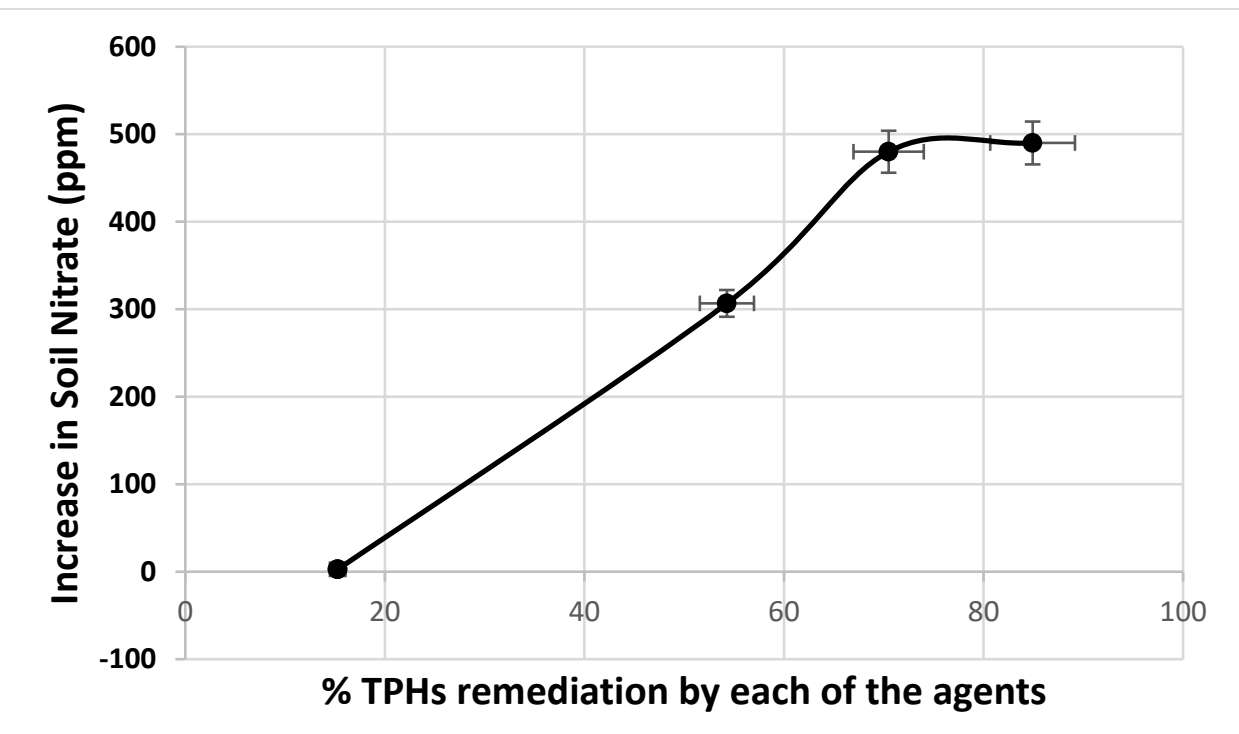

Figure 1: Variation in soil nitrates with \% reduction in TPHs during remediation of petroleumcontaminated soils from Tibshelf, UK (Error bars represents standard deviation $\delta$ ). The figure is a plot of the \% reduction in TPHs by each of the agents against the corresponding increase in soil nitrates associated with each agent during such remediation. For instance, \% remediation was obtained my subtracting the levels of TPHs at time $=0$, and time $=90$ days for a particular agent. The increase in nitrate level as also similarly evaluated (at time $=0$, time $=90$ days for each of the agents). The curve shows a steady rise of available nitrate with increase remediation and peaks at remediation efficiency of $70 \%$. These points correspond to TPHs concentrations in uncontaminated soils.

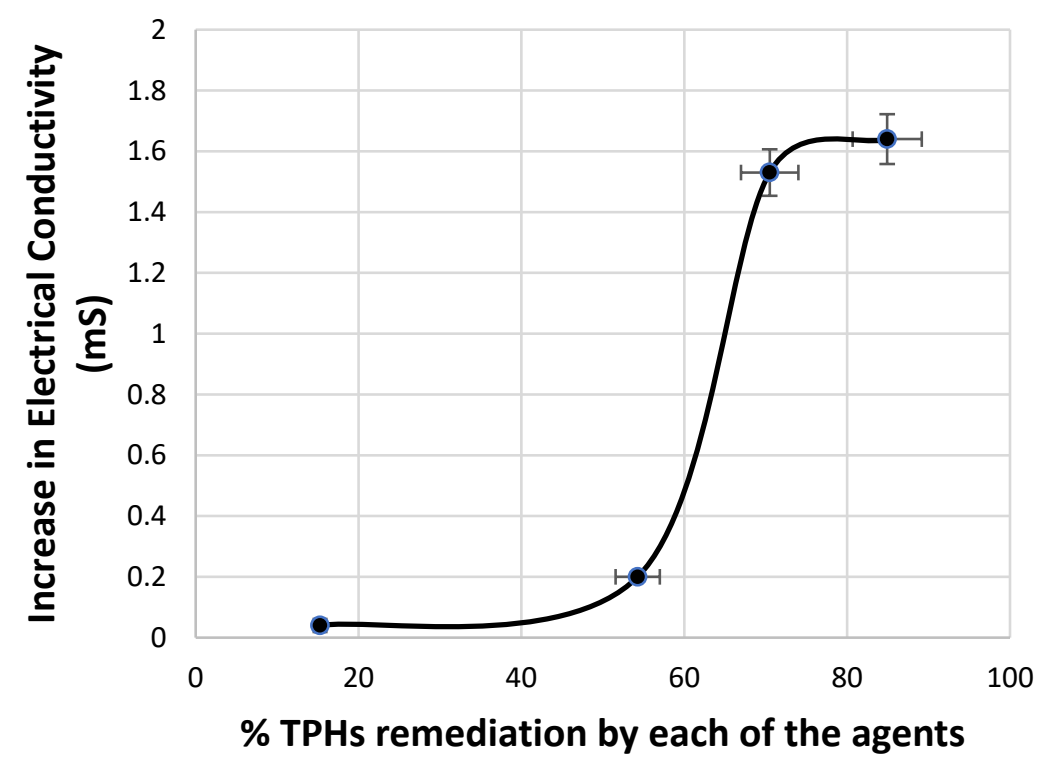

Figure 2: Variation of soil's EC with \% reduction in TPHs during remediation of petroleum contaminated soils from Tibshelf, UK (Error bars represents standard deviation $\delta$ ). The figure is a plot of the \% reduction in TPHs by each of the agents against the corresponding increase in soil electrical conductivity associated with each agent during such remediation. For instance, \% remediation was obtained my subtracting the levels of TPHs at time $=0$, and time $=90$ days for a particular agent. The increase in electrical conductivity level as also similarly evaluated (at time $=0$, time $=90$ days for each of the agents). The curve shows a steady rise of electrical conductivity with increase remediation and peaks at remediation efficiency of $70 \%$. These points correspond to TPHs concentrations in uncontaminated soils. 


\subsection{Remediation efficiencies of sunflower species, fermented palm wine and $\boldsymbol{P}$. ostreatus on the petroleum-contaminated soils}

All the agents used in the treatment of the petroleum-contaminated soils demonstrated noticeable remediation efficiency after 90 days (Figure 3). A comparison of remediation efficiencies of the agents revealed the following order: $P$. ostreatus $>$ palm wine $>$ sunflower species (Table 4). This was based on the enhanced application method of mixing substrates and mushrooms with soils followed by layering. With respect to the typical method of layering mushrooms and substrates on soils, remediation efficiency of the agents was observed as Palm wine $>$ P. ostreatus $>$ sunflower species.

Table 4: Percentage reductions in TPHs levels in petroleum contaminated soils treated with sunflower species, fermented palm wine and $P$. ostreatus

\begin{tabular}{|l|l|l|}
\hline Samples/Treatment & $\begin{array}{l}\text { \% reduction } \\
\text { In TPHs contents of soils } \\
\text { between T=0 days and } \\
\text { T=90 days }\end{array}$ & $\begin{array}{l}\text { p-values } \\
\text { (@ 95\% CI) of } \\
\text { T=90 days values } \\
\text { against T=0 days }\end{array}$ \\
\hline $\begin{array}{l}\text { Untreated Petroleum-contaminated soil } \\
\text { (Control) }\end{array}$ & 15 & $\mathbf{0 . 2 9 4}$ \\
\hline $\begin{array}{l}\text { Petroleum-contaminated soil + H. annus } \\
\text { (Sunny dwarf) }\end{array}$ & 54 & 0.001 \\
\hline Petroleum-contaminated soil + H. sunsation & 53 & 0.003 \\
\hline $\begin{array}{l}\text { Petroleum-contaminated soil + H. annus } \\
\text { (Pacino gold) }\end{array}$ & 69 & 0.011 \\
\hline $\begin{array}{l}\text { Petroleum-contaminated soil + fermented } \\
\text { palm wine from E. guineensis }\end{array}$ & 70 & 0.001 \\
\hline $\begin{array}{l}\text { Petroleum-contaminated soil + fermented } \\
\text { palm wine from } R \text {. africana }\end{array}$ & 69 & 0.000 \\
\hline $\begin{array}{l}\text { Petroleum-contaminated soil + P. ostreatus } \\
\text { without substrates }\end{array}$ & 29 & 0.000 \\
\hline $\begin{array}{l}\text { Petroleum-contaminated soil + P. ostreatus }+ \\
\text { substrates layered on soil }\end{array}$ & 60 & 0.000 \\
\hline $\begin{array}{l}\text { Petroleum-contaminated soil + P. ostreatus + } \\
\text { substrates mixed with soils and layered }\end{array}$ & 85 & \\
\hline
\end{tabular}

p-values are for T-test on TPHs concentrations at $T=0$ days against Time $=90$ days, to see if TPHs concentrations at Time $=90$ days (after remediation) are significantly different from $T=0$ days (before remediation). Raw data are in Appendix III-2. P-values highlighted in bold signify results where there is no significant differences in TPHs values at Time $=0$ days and 90 days $(p>0.05)$. Those not highlighted in bold signify results where there is significant differences between in TPHs values at time $=0$ days and 90days. 


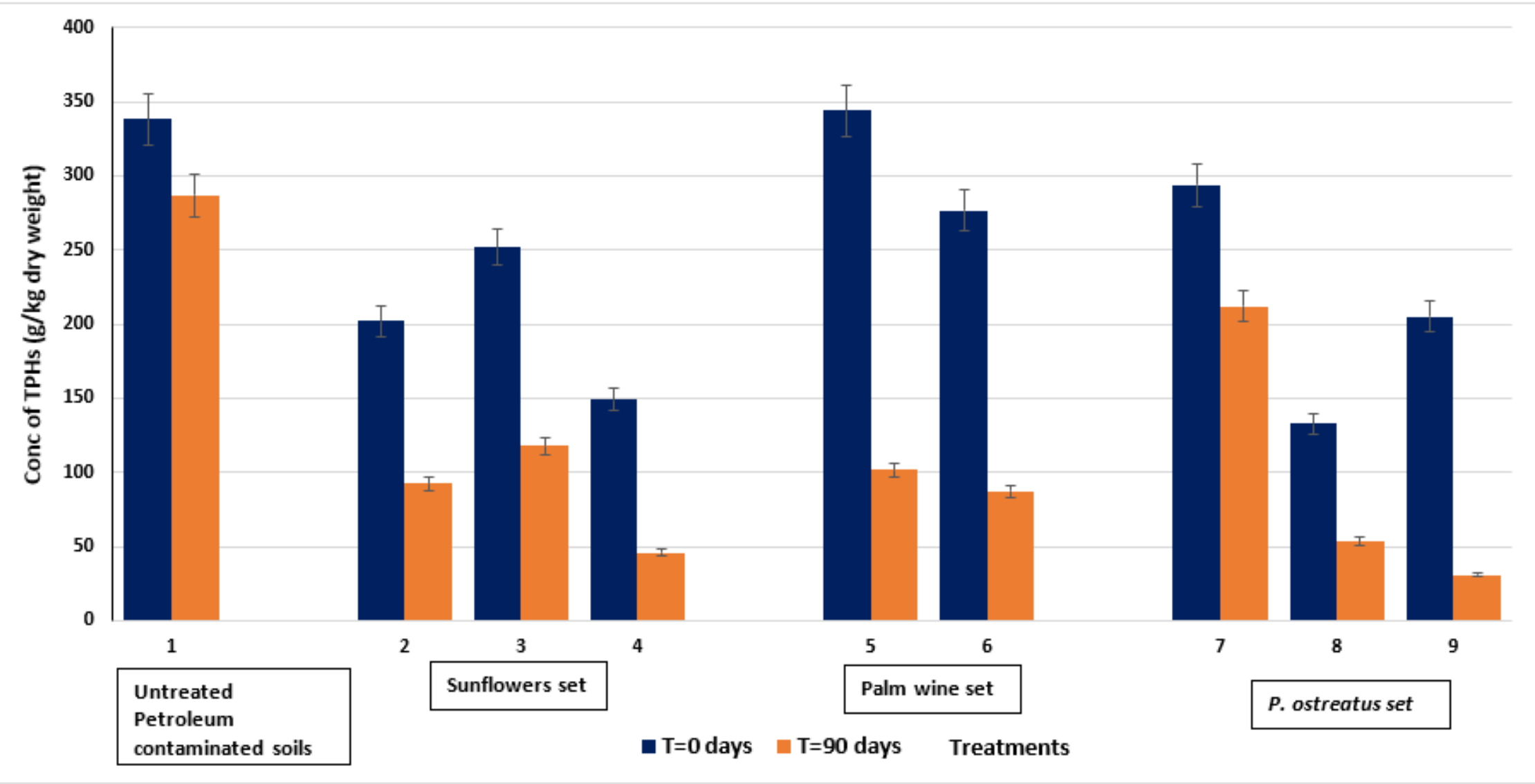

Figure 3: Levels of TPHs in soils at start of remediation ( $T=0$ days) and after $T=90$ days of treatments with the different agents. Errors bars represents standard deviation from the mean of triplicate analysis. Raw values are available in Appendix III-2: Treatment numbers are as follows:

(1). Untreated Petroleum-contaminated soil (Control); (2). Contaminated soil + Helianthus annus (Sunny dwarf); (3). Contaminated soil + Helianthus sunsation (4). Contaminated soil + Helianthus annus (Pacino gold); (5). Contaminated soil + fermented palm wine from Elaeis guineensis (6). Contaminated soil + fermented palm wine from Raffia Africana (7). Contaminated soil $+P$. ostreatus without substrates (8). Contaminated soil $+P$. ostreatus + substrates layered on soil (9). contaminated soil $+P$. ostreatus + substrates mixed with soils and also layered 
For the sunflower species, highest percentage reduction in TPHs was obtained with $H$. annus (Pacino gold) and was 69\% (Table 4). This was followed by H. annus (Sunny dwarf) (54\%) and lastly by $H$. sunsation (53\%). Phytoremediation efficiencies of the sunflower species were significant $(p<0.05)$ compared to those of control soils. Similar remediation efficiency was observed in the remediation potential of $H$. sunsation and $H$. annus (Sunny dwarf) ( $p>0.05)$. Remediation efficiency of $H$. annus (pacino gold) was observed to be significantly higher $(p<0.05)$ than those of both $H$. sunsation and $H$. annus (Sunny dwarf) (Table 4).

Physiological parameters such as height and biomass of sunflower plants were negatively affected by presence of petroleum contaminants in soils. Plants growing in contaminated soils had lower height and biomass. Positive correlation was also observed between phytoremediation efficiency of sunflower species and their biomass (Figure 4). $\mathrm{H}$. annus (Pacino gold) had both the highest biomass and remediation efficiency with respect to TPHs on the petroleum-contaminated soil.

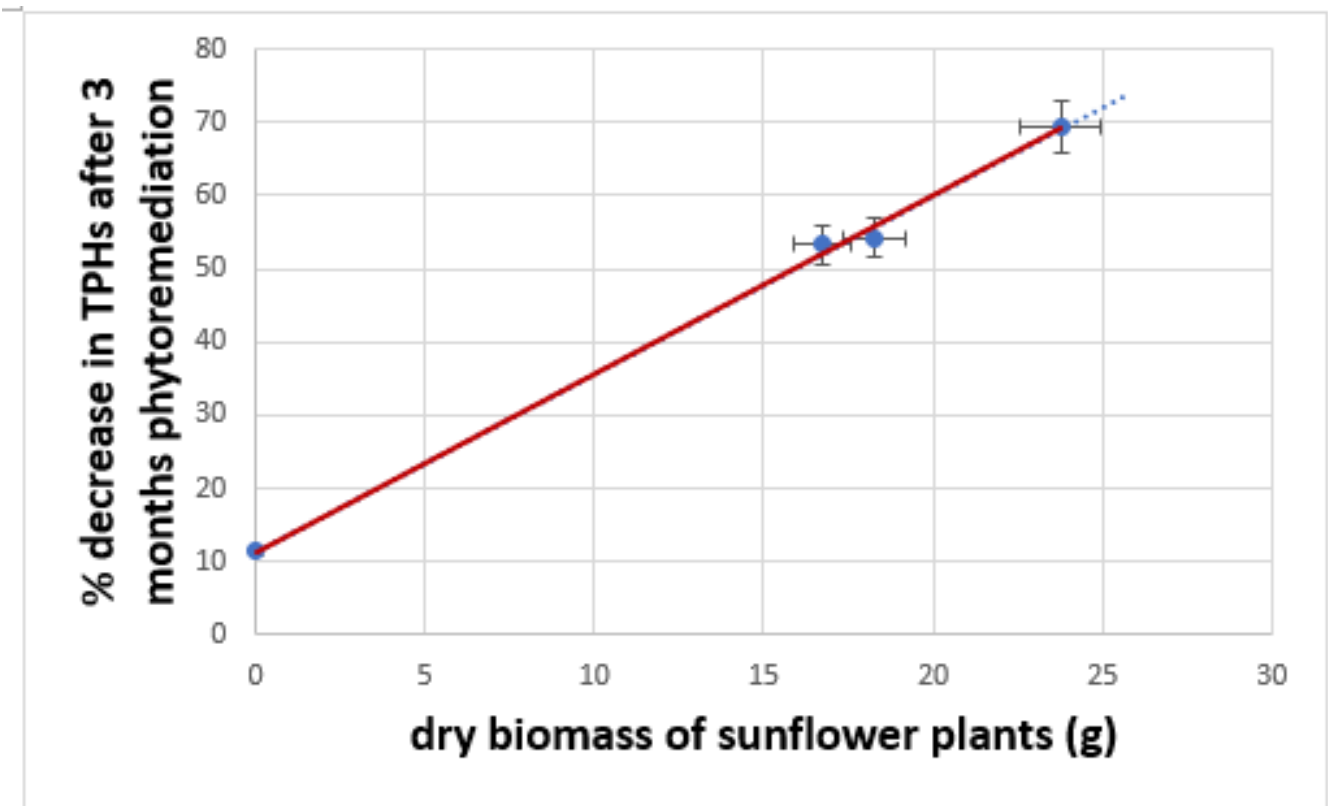

Figure 4: Correlations between remediation efficiencies (\% decrease in TPH) and dry biomass of sunflower plants. Errors bars represents standard deviation of the mean. 
Fermented palm wine from the two species of palm trees (E. guineensis and $R$. africana) each demonstrated significant remediation potential $(p<0.05)$ on the petroleum-contaminated soils compared to controls (Figure 3). Palm wine from E. guineensis effected up to $70 \%$ reduction of TPHs while that from $R$. africana was $69 \%$ (Table 4). There was however, no significant difference $(p=0.000)$ between remediation efficiencies of fermented palm wine obtained from $E$. guineensis or R. africana.

Investigation of alternative substrates for growing $P$. ostreatus, revealed that the mushroom germinated and grew faster under sterilised conditions (Table 2). Growth of $P$. ostreatus was still achieved under unsterilised conditions at temperatures of $10-15^{\circ} \mathrm{C}$. Shorter timeframe was observed for germination and fruiting of $P$. ostreatus with substrates such as palm tree and pine bark compared to others. The effectiveness of these substrates to support the growth of the mushroom can also be related to their lignin contents (Table 2). P. ostreatus was able to grow faster on substrates with higher lignin contents. Pine bark and palm tree substrates exhibited better growth even in unsterilised conditions.

The highest remediation efficiency of $85 \%$ for TPHs in soils treated with $P$. ostreatus was obtained by the method of mixing both mushrooms and substrates with soils combined with layering. This was followed by layering substrates and mushrooms on soil $(60 \%)$, while the method of mixing mushrooms spawn with soils without substrates resulted in $28 \%$ TPHs reduction (Table 4). Application of $P$. ostreatus using the combined method of mixing mushrooms and substrates with soils, and layering resulted in $25 \%$ increase in remediation efficiency compared to the usual method of layering. There was also a significant difference in remediation efficiency between contaminated soils treated by layering $P$. ostreatus with substrates and the control (Table 4). Although there were reductions in TPHs in untreated soils and those treated with $P$. ostreatus without substrates (Table 4), the difference was not significant $(p=0.294)$ when compared to the TPHs values in soils at Time $=0$ and Time $=90$ days.

\section{Discussion}

\subsection{Physicochemical properties of the soils}

From particle size analysis, the soil from Tibshelf, Derbyshire, can be categorised as clayey loam. Higher levels of clay particles in the petroleum-contaminated soils suggest soil particle degradability by crude oil on soil (Okoro et al., 2011). The soil acidification by petroleum contaminants observed in this study corroborated those of Gogoi et al. (2003) and Osuji \& 
Nwoye (2007) and is related to the constituents (acids and acids anhydrides) of the contaminating petroleum (Sarkar et al., 2005). As observed in this study, Whalen et al. (2000) reported that cow manure can be used to amend acidic soil to near neutrality. Therefore, the $\mathrm{pH}$ condition (8.50-8.9) induced by the addition of cow manure in the present study provided suitable conditions for the remediation to proceed (Gogoi et al., 2003). The increased pH favoured the solubility and bioavailability of the hydrophobic petroleum contaminants which in turn increased their degradation (Jardine et al., 1989).

From the present investigations, it was observed that high levels of petroleum contamination resulted in low levels of nitrate in soils and vice versa which is in line with the findings of John et al. (2016). When these contaminants were taken out of the soils during remediation, more nitrate that were immobilised, were released (Table 2). The observed reduction in available nitrate with high petroleum contamination is related to the great affinity for organic compounds such as organic matter by soil nitrate (Taylor \& Townsend, 2010). Therefore, some of the nitrate is sequestered by the high organic content of the petroleum making them unavailable in soil solutions. In addition, the petroleum contaminants also take up much of the soil pores thereby reducing nitrate availability. The addition of cow manure increased organic matter (with nitrate-attracting functional groups such as carboxylic acids and hydroxyl groups); and moisture contents (Raviv et al., 2004) and consequently diluted the concentration of the petroleum contaminants. Thus, more nitrates were available in soil solutions.

Khamehchiyan et al. (2007) described increase in physicochemical properties of petroleumcontaminated soils on addition of organic manure. In this study, the addition of cow manure to the petroleum-contaminated soils increased soil $\mathrm{pH}$, electrical conductivity and available nitrate. As remediation progressed, levels of soils nitrate and electrical conductivity increased and was proportional to the remediation efficiency of the agents (Figure 1). Thus, available nitrate and electrical conductivity can serve as possible useful indicators of TPHs remediation progress in petroleum-contaminated soils.

\subsection{Phytoremediation efficiency of the agents}

Variation in TPHs levels in the soil samples of the glasshouse is due to the non-homogeneity of the petroleum contaminants in the soil matrix. Variable concentration of TPHs is expected 
in soils due to factors such as proximity to contaminants source, duration of impact, constituent soil particles, soil structure and chemistry (Yang et al., 2015). Furthermore, the soil samples from Tibshelf had predominant clay particles (Table 2) which are crumby and difficult to break. These crumbs each accumulate peculiar levels of the petroleum contaminants. In this study, the soil samples were mixed by hand, there is also the chances of poor homogeneity. These factors all resulted in the observed variability in TPHs levels at T=0 days in the soil samples (Xing et al., 2011).

The general observation in this study was that the levels of TPHs at Time $=90$ days was proportional to their respective levels at Time $=0$ days. For instance, for the sunflower species, TPHs concentrations at time $=0$ was 200 and $90 \mathrm{~g} / \mathrm{Kg}$ at time $=90$ days for $\mathrm{H}$. annussunny dwarf and 250 and $120 \mathrm{~g} / \mathrm{Kg}$ for $\mathrm{H}$. sunsation. This trend also holds for the palm wine set (340 and $100 \mathrm{~g} / \mathrm{Kg}$ for E. guineensis; 280 and $90 \mathrm{~g} / \mathrm{Kg}$ dry soil for $R$. africana at time = 0 and 90 days, respectively). Winquist et al. (2014) demonstrated a 96\% degradation of PAHs with an initial concentration of $3500 \mathrm{mg} / \mathrm{kg}$ in a glasshouse, and $94 \%$ during a field study with an initial concentration of $1400 \mathrm{mg} / \mathrm{kg}$ of soil, after three months. Thus, it is reasonably assumed that the initial levels of TPHs at the start of the remediation does not affect the remediation potentials of the agents. Hence, the variability in initial concentrations of TPHs among sample treatment sets can be accommodated.

Although the samples labelled 1 (figure 3) were not treated, natural attenuation plays a part in reduction of TPHs in soils, however, the progress is very slowed, and most times insignificant (O’Brien et al., 2019).

\section{Sunflower species}

Plants can phyto-extract, phyto-degrade or phytostabilise organic contaminants in soils (Pilon-Smits, 2005). Thus, the sunflowers could utilise any of these mechanisms. Hassan et al., (2018) demonstrated a phytoremediation efficiency of up to $56 \%$ with sunflower (H. annus) in the remediation of crude oil contaminated soils supplanted with inorganic fertilisers. Liduino et al. (2018) demonstrated up to $58 \%$ and $48 \%$ reduction of TPHs by sunflowers ( $H$. annus $L$.) supplanted by biosurfactants on petroleum-contaminated soils after three months. A similar range of phytoremediation efficiencies (53\%, 54\%) was observed for 2 of the 
sunflower species used in the present study, substantiating the potential of sunflowers for remediation of petroleum-contaminated soils. The sunflower plants could not grow in the high concentrations of crude oil in the soils of the present study without amendment, but only on the amended soils. The use of cow manure as a source of amendment in this study demonstrated that organic manures can be used to successfully initiate phytoremediation of petroleum-contaminated soils.

The reduction in height and biomass of the sunflower plants observed in the present investigation are comparable to that of Brandt et al. (2006). These reductions can be attributed to difficulties in adapting to the stress environment, insufficient nutrients or toxicity of the petroleum contaminants (Merkl et al., 2005). John (2016) reported that soil contamination by crude oil leads to a reduction in nutrient parameters such as available nitrate with a marked reduction in water uptake. These are essential factors for plants growth. Thus, any constrain which negatively affects nutrients and water availability would invariably result in poor growth and biomass yield.

Robinson et al. (1998) stated that phytoremediation efficiency is influenced by biomass of plants. Plant species with higher biomass are known to exhibit better phytoremediation potential (Chekol et al., 2004). Both $H$. annus (sunny dwarf) and $H$. sunsation exhibited similar heights and biomass. The measured height and biomass of $H$. annus (Pacino gold) was observed to be significantly higher than those of $H$. annus (sunny dwarf) and $H$. sunsation. Therefore, the remediation efficiency of the sunflower species with respect to TPHs is related to their biomass (Figure 4). This finding is important for real life in-situ application. It implies that using sunflower species with high biomass can produce better results in the treatment of petroleum-contaminated soils. In addition to the effectiveness at remediating TPHs, the use of sunflowers will provide the additional benefits of removing trace metals and other pollutants, with aesthetic appeal (Hull et al., 2000; Chauhan \& Mathur, 2018).

\section{Fermented palm wine}

Chandrasekhar et al. (2012) stated that fermented palm wine consists principally of yeast of the Saccharomyces species. A consortium of microbial species such as yeast, candida, pichia, lactobacillus and acetobacter are also found in palm wine (Santiago-Urbina \& Ruíz-Terán, 
2014; Nwaiwu et al., 2016). Therefore, the remediation potential of palm wine may be a synergy among the different species of microorganisms present in the fermentation product (Santiago-Urbina \& Ruíz-Terán, 2014). Enhanced remediation of petroleum-contaminated soils by synergistic microbial relationships is well known (Fan \& Qin, 2014). Chandrasekhar et al. (2012) and Nwaiwu et al. (2016) also reported that fermented palm wine chemically consists of mixtures of alcohol such as ethanol, propanol and methanol; esters like ethyl propanoate; and organic acids such as ethanoic, methanolic and propanoic acids. These compounds are organic solvents and can act as surface-active agents (Stjerndahl et al., 2019). Therefore, the observed remediation potentials of fermented palm wine could be the result of the combined actions of a consortium of microorganisms and that of surfactants organic compounds.

The observed similarity in the remediation potentials of fermented palm wine on petroleumcontaminated soils from the two species of palms trees indicated that palm wine obtained from these sources may be of similar microbial or chemical constituents. This implies that palm wine from other palm trees can be used for the treatment of petroleum-contaminated soils. The use of fermented palm wine for remediation of petroleum-contaminated soils is very promising because there are varieties of palm trees for the supply of palm wine in tropical climates like the Niger Delta, Nigeria (Asuk et al., 2018). Application of fermented palm wine for remediation of petroleum-contaminated soils as observed in this study did not required much expertise and preconditioning, substrates or nursery activities. The fermented Palm wine can easily be applied directly to the soil. This makes it a method of choice compared to the other agents used in the study.

\section{P. ostreatus}

\section{Investigation of alternative substrate for growing $P$. ostreatus}

Adenipekun and Lawal (2012) stated that substrates sterilisation helped in the decontamination of other microflora, which can compete and slow down the growth of white rot mushrooms. Thus, the mushrooms could grow faster in sterilised substrates due to absence of competition from other microflorae. However, the destruction of these natural microflorae by sterilisation can eliminate their activities which may be useful in the remediation processes. It was, therefore, necessary to investigate the feasibility of growing the mushrooms without sterilisation. This investigation revealed that $P$. ostreatus can still 
grow in substrates without sterilisation (Table 2). The outcome is useful for potential in situ application since it saves energy and removes the need for sterilisation equipment. It would also allow for the contribution of natural microflora towards the remediation process.

White rot mushrooms such as P. ostreatus naturally feed on lignin (Rabinovich et al., 2004); therefore, substrates with higher lignin contents should favour its growth. P. ostreatus germinated and fruited faster in substrates with higher lignin contents (Table 2). A further study to also investigate the types of lignin present in these substrates and possible application of biotechnology for extraction is required. This would aid their commercial preparations for prospective use in the treatment of petroleum-contaminated soil. The cultivation of white rot mushrooms on palm substrates is yet to be reported; therefore, this investigation has added palm trees as promising substrates for the cultivation of white rot mushrooms. Palm substrates will also serve as valuable substrates for the application of mycoremediation on petroleum-contaminated soil, particularly in tropical regions like the Niger Delta, Nigeria.

\section{Effects of application procedures on mycoremediation efficiency of $P$. ostreatus}

Typical method of application of $P$. ostreatus on petroleum-contaminated soils is by layering (Stamet, 2005; Adenipekun et al., 2015). The results in this study demonstrated that mixing palm tree substrates and mushrooms with soil combined with layering on topsoil resulted in significant enhancement $(p=0.000)$ of mycoremediation efficiency of $P$. ostreatus on the petroleum-contaminated soils even under unsterilized conditions (Table 5). The observations can be attributed to an increase in surface area of contact between the mushrooms and the hydrocarbon contaminants in the soil matrix. Since these substrates were not sterilised, activities of other microorganisms may also contribute to the observed results.

Adenipekun and Fasidi (2005) obtained a biodegradation of $20 \%$ after 3 months and $40 \%$ after 6 months on petroleum-contaminated soils. Mehrasbi et al. (2003) reported remediation efficiencies of $36 \%, 55 \%$ and $60 \%$ after 6 months. The results obtained by layering in this study under unsterilised conditions are comparable to those of Adenipekun and Fasidi (2005), Mehrasbi et al., (2003), Chiu et al., (2009) and Adenipekun et al., (2015) using P. ostreatus under sterilised conditions. However, the remediation efficiency obtained by method of mixing the substrates and mushrooms with soils combined with layering, is much higher than those of these literatures. The soils used in this study had very high initial levels of TPHs and 
were conventional petroleum-contaminated soils taken from a site with proximity to an exuding oil well at Tibshelf, UK. Thus, the remediation outcome of $P$. ostreatus (85\%) under these conditions is unique.

Although mushrooms can grow straight from spawn without substrates, most times this is not ideal (Royse, 2002). Meysami and Baheri (2003) reported that substrates are required for action of white rot fungi on petroleum-contaminated soils. Mamiro \& Royse (2008) stated that a small quantity of mushrooms spawn can inoculate a much greater amount of substrate resulting in better mushrooms growth and yield compared to using the spawn alone. The low remediation efficiency in TPHs contents obtained in untreated soils and those treated with $P$. ostreatus without substrates (Figure 3) are comparable to those of Meysami and Baheri (2003). The present investigation verified that a suitable substrate is required for the application of mycoremediation on petroleum-contaminated soils. The use of palm substrates resulted in up to $60 \%$ reduction in TPHs with layering and $85 \%$ when the substrates are both mixed with the soils and also layered under unsterilised conditions. A comparison of remediation efficiency for the methods of layering of substrates, with that of mixing the mushrooms and substrate with soils combined with layering, revealed an increase of about $25 \%$ for the later. Thus, substrates type, and method of application can influence mycoremediation efficiency of white rot fungi on petroleum-contaminated soils.

The application procedure of mixing the substrates and mushrooms with soils combined with layering is advantageous for in situ applications of mycoremediation on petroleumcontaminated soils. Palm substrates can be ploughed into contaminated soils followed by the inoculation of the mushroom spawns for remediation of petroleum-contaminated soils. The combination of the mixing procedures with layering would also allow for protection of the remediation process against precipitation agents such as heavy rains, which are common in tropical climates (Yabi \& Afouda, 2012). Thus, the spawns underneath the layered samples could continue the remediation almost undisturbed even during rainy seasons.

Commercial mushroom spawns are usually available as grain or sawdust spawns (Chang \& Hayes, 2013). There is therefore, the possibility for the development of sawdust spawn of $P$. ostreatus using palm tree substrates, which could be used for remediation of petroleumcontaminated soils. Overall, mixing the substrates and mushroom with soils followed by 
layering, resulted in optimisation of the mycoremediation efficiency of $P$. ostreatus compared to the usual method of layering.

\section{Conclusion}

This study investigated the potentials of sunflower species, fermented palm wine and $P$. ostreatus for treatment of petroleum-contaminated soils. The main conclusions are as follows:

$>$ Cow manure can be used to increase soil nutrients, decrease acidity in soils and provide buffer for soil during remediation of petroleum-contaminated soils.

> Soils available nitrate and electrical conductivity increases with remediation efficiency and can be used to monitor remediation progress of petroleum-contaminated soils.

$>$ Phytoremediation efficiency of sunflower species could be related to their biomass, with those having higher biomass exhibiting better remediation potentials.

$>$ Fermented palm wine can be used for the remediation of petroleum-contaminated soils.

$>$ Palm tree substrates can be used for growing white rot mushrooms under unsterilized conditions. The substrate can also be used for the application of white rot mushrooms on petroleum-contaminated soils.

$>$ Mycoremediation potential of $P$. ostreatus can be enhanced by an application method of mixing the substrates and mushrooms with the contaminated soil combined with layering.

$>$ Mycoremediation efficiency of white rot mushrooms on petroleum-contaminated soil depends on the application method and type of substrates.

The concept of phyto-and myco-remediation has been developed overtime with many challenges and short-comings. The present study goes beyond the remediation of petroleumcontaminated soils by sunflowers to the assessment of the remediation efficiency with species; and has established that this varies with biomass. This information is important in the choice of sunflowers for remediation. The use of fermented palm wine for treatment of petroleum-contaminated soils is novel and is useful for tropical regions where palm trees are abundant. Adapting P. ostreatus for use in the clean-up of petroleum-contaminated soils has been problematic. The present study has developed a realistic approach and with a novel 
substrate (Palm tree which is abundant in tropical regions) for application of $P$. ostreatus in the clean-up of petroleum-contaminated soils.

The applications of these phyto- and myco-remediation techniques can provide environmentally friendly options for treatment of petroleum-contaminated soils. These techniques would be beneficial to tropical regions like the Niger Delta, Nigeria because of the abundance of the phyto - and mycoremediation resources such as palm trees and palm wine. The methods would also provide readily available and cost-effective alternatives for the management of petroleum-contaminated soil.

\section{References}

Abdul Khalil, H. P. S., Siti Alwani, M., Ridzuan, R., Kamarudin, H., and Khairul, A. (2008). Chemical composition, morphological characteristics, and cell wall structure of Malaysian oil palm fibers. Polymer-Plastics Technology and Engineering, 47(3): 273- 280.

Adenipekun, C. O. and Fasidi, I. O. (2005). Bioremediation of oil-polluted soil by Lentinus subnudus, a Nigerian white-rot fungus. African Journal of Biotechnology, 4(8):796-798.

Adenipekun, C. O., Ipeaiyeda, A. R., Olayonwa, A. J. and Egbewale, S. O. (2015). Biodegradation of polycyclic aromatic hydrocarbons (PAHs) in spent and fresh cutting fluids contaminated soils by Pleurotus pulmonarius (Fries). Quelet and Pleurotus ostreatus (Jacq.) Fr. P. Kumm. African Journal of Biotechnology, 14(8): 661- 66.

Adenipekun, C.O. and Lawal, R. (2012). Uses of Mushrooms in Bioremediation: A review. Biotechnology and Molecular Biology Reviews, 7(3):62-68.

Albert, E., Anyanwu, D. I. and Kim, K.-H. (2016). Evaluation of Composting with "Spent" Mushroom Substrate and Sawdust for Remediation of Petroleum Hydrocarbon- Polluted Soil. Journal of Agriculture and Ecology Research International Philippines, 9(91): 1-9.

Al-Nasrawi, H. (2013). Biodegradation of Crude Oil by Fungi Isolated from Gulf of Mexico. Journal of Bioremediation and Biodegradation, 3(4):1-6.

Asuk, S. A., Offiong, E. E., \& Ifebueme, N. M. (2018). Species composition and diversity of mangrove swamp forest in southern Nigeria. International Journal of Avian \& Wildlife Biology, 3(2): 166-171.

Brandt, R., Merkl, N., Schultze-Kraft, R., Infante, C., \& Broll, G. (2006). Potential of vetiver (Vetiveria zizanioides (L.) Nash) for phytoremediation of petroleum hydrocarboncontaminated soils in Venezuela. International journal of phytoremediation,8(4): 273-284.

BS EN ISO 16703 (2011). Soil Quality-Determination of Content of Hydrocarbon in the Range C10 to C40 by Gas Chromatography.

BS EN ISO/DIS 18400: 101-107(2016). Soil Quality Sampling; Packaging, Transport, Storage and Preservation of Samples. 
Chandrasekhar, K., Sreevani, S., Seshapani, P., \& Pramodhakumari, J. (2012). A review on palm wine. International Journal of Research in Biological Sciences, 2(1), 33-38.

Chang, S. T., \& Hayes, W. A. (Eds.). (2013). The biology and cultivation of edible mushrooms. Academic press.

Chauhan, P., \& Mathur, J. (2018). Potential of Helianthus annuus for phytoremediation of multiple pollutants in the environment: A Review. Journal of Biological Sciences and Medicine, 4(3), 5-16.

Chekol, T., Vough, L. R., \& Chaney, R. L. (2004). Phytoremediation of polychlorinated biphenylcontaminated soils: the rhizosphere effect. Environment international, 30(6), 799-804.

Chhatre, S., Purohit, H., Shanker, R., \& Khanna, P. (1996). Bacterial consortia for crude oil spill remediation. Water Science and Technology, 34(10), 187-193.

Chiu, S. W., Gao, T., Chan, C. S. S., \& Ho, C. K. M. (2009). Removal of spilled petroleum in industrial soils by spent compost of mushroom Pleurotus pulmonarius. Chemosphere, 75(6), 837-842.

Ciurli, A., Lenzi, L., Alpi, A. and Pardossi, A. (2014). Arsenic Uptake and Translocation by Plants in Pot and Field Experiments. International Journal of Phytoremediation, 16:804-823.

Daud, Z., Awang, H., Kassim, A. S. M., Hatta, M.Z.M. and Arinpin, A. M. (2014). Comparison of Pineapple Leaf and Cassava Peel by Chemical Properties and Morphology Characterization. Advanced Materials Research 974: 384-388.

Diab, E. A. (2008). Phytoremediation of oil contaminated desert soil using the rhizosphere effects. Global Journal of environmental research, 2(2), 66-73.

Dickson, U. J., \& Udoessien, E. I. (2012). Physicochemical Studies of Nigeria's Crude Oil Blends. Petroleum \& Coal, 54(3).

Dickson, U. J., Coffey, M., Mortimer, R. J. G., Di Bonito, M., \& Ray, N. (2019). Mycoremediation of petroleum contaminated soils: progress, prospects and perspectives. Environmental Science: Processes \& Impacts. DOI: 10.1039/c9em00101h.

Dominguez-Rosado, E., Pichtel, J., \& Coughlin, M. (2004). Phytoremediation of soil contaminated with used motor oil: I. Enhanced microbial activities from laboratory and growth chamber studies. Environmental Engineering Science, 21(2), 157-168.

Fan, M. Y., Xie, R. J., \& Qin, G. (2014). Bioremediation of petroleum-contaminated soil by a combined system of biostimulation-bioaugmentation with yeast. Environmental technology, 35(4), 391-399.

Gatfaoui, H. (2016). Linking the gas and oil markets with the stock market: Investigating the U.S. relationship. Energy Economics 53: 5-16. 
Gogoi, B. K., Dutta, N. N., Goswami, P., \& Mohan, T. K. (2003). A case study of bioremediation of petroleum-hydrocarbon contaminated soil at a crude oil spill site. Advances in Environmental Research, 7(4), 767-782.

Hampton, C., Leowenthal, M., \& Smith, R. (2019). Real time monitoring of nitrate at farm wells in the Cotswold Oolite. Quarterly Journal of Engineering Geology and Hydrogeology, qjegh2018-113.

Hassan, M., Abdelhamid, M., Nassef, O. A., \& Abdel Harith, M. (2018). Spectrochemical Analytical Follow up of Phytoremediation of Oil-Contaminated Soil. Soil and Sediment Contamination: An International Journal, 27(6), 485-500.

Hull, R. B., Robertson, D. P., Buhyoff, G. J., \& Kendra, A. (2000). What are we hiding behind the visual buffer strip? Forest aesthetics reconsidered. Journal of Forestry, 98(7), 34-38.

IEA-International Energy Agency (2014). Key World Energy Statistics. Lea.org. IEA pp;6,8.

Izah, S. C., \& Seiyaboh, E. I. (2018). Changes in the Protected Areas of Bayelsa State, Nigeria. International Journal of Molecular Evolution and Biodiversity, 8(1): 1-11.

Jardine, P.M., Weber, N.L., and McCarthy, J.F. (1989). Mechanisms of dissolved organic carbon adsorption on soil. Soil Science Society of America Journal, 53: 1378- 1385.

John, R. C., Ntino, E. S., and Itah, A. Y. (2016). Impact of crude oil on soil nitrogen dynamics and uptake by legumes grown in wetland ultisol of the Niger Delta. Nigerian Journal of Environmental Protection, 7(04: 507.

Joshua, J. A., Ahiekpor, J. C., and Kuye, A. (2016). Nigerian hardwood (Nesogordonia papaverifera) sawdust characterization: Proximate analysis, cellulose and lignin contents. Lignocellulose 5(1): 50-58.

Khamehchiyan, M., Charkhabi, A. H., \& Tajik, M. (2007). Effects of crude oil contamination on geotechnical properties of clayey and sandy soils. Engineering geology, 89(3-4): 220-229.

Kogbara, R. B., Dumkhana, B. B., Ayotamuno, J. M., \& Okparanma, R. N. (2017). Recycling stabilised/solidified drill cuttings for forage production in acidic soils. Chemosphere, 184, 652663.

Kogbara, R. B., Ogar, I., Okparanma, R. N., \& Ayotamuno, J. M. (2016). Treatment of petroleum drill cuttings using bioaugmentation and biostimulation supplemented with phytoremediation. Journal of Environmental Science and Health, Part A, 51(9), 714-721.

Liduino, V. S., Servulo, E. F., \& Oliveira, F. J. (2018). Biosurfactant-assisted phytoremediation of multi-contaminated industrial soil using sunflower (Helianthus annuus L.). Journal of Environmental Science and Health, Part A, 53(7), 609-616.

Mamiro, D. P. and Royse, D. J. (2008). The influence of spawn type and strain on yield, size and mushroom solids content of Agaricus bisporus produced on non-composted and spent mushroom compost. Bioresource technology, 99(8): 3205-3212. 
Mehrasbi, M.R., Haghighi, B., Shariat, M., Naseri, S. \& Naddafi, K. (2003). Biodegradation of Petroleum Hydrocarbons in Soil. Iranian Journal of Public Health, 32(3): 28-32.

Meredith, W., Kelland, S. J., \& Jones, D. M. (2000). Influence of biodegradation on crude oil acidity and carboxylic acid composition. Organic Geochemistry, 31(11): 1059-1073.

Meysami, P., \& Baheri, H. (2003). Pre-screening of fungi and bulking agents for contaminated soil bioremediation. Advances in Environmental Research, 7(4), 881-887.

Nwaiwu, O., Ibekwe, V., Amadi, E., Udebuani, A., Nwanebu, F., Oguoma, O., \& Nnokwe, J. (2016). Evaluation of fermentation products of palm wine yeasts and role of Sacoglottis gabonensis supplement on products abundance. Beverages, 2(2), 9.

O'Brien, P. L., DeSutter, T. M., \& Casey, F. X. (2019). Natural degradation of low-level petroleum hydrocarbon contamination under crop management. Journal of Soils and Sediments, 19(3), 1367-1373.

Okoro, D., P.O. Oviasogie and F.E. Oviasogie (2011) Soil quality assessment 33 months after crude oil spillage and clean-up, Chemical Speciation \& Bioavailability, 23:1-6.

OLÁR, R., Melcer, I. and Kačík, F.(1988). Comparative study of pine wood and pine bark (Pinus silvestris L.) dioxan lignins. Cellulose Chemistry and Technology, 22: 39-52.

Osuji, L. C., \& Nwoye, I. (2007). An appraisal of the impact of petroleum hydrocarbons on soil fertility: the Owaza experience. African journal of agricultural research, 2(7), 318-324.

Pilon-Smits, E. (2005), Phytoremediation, Annual Reviews of Plant Biology 56: 15-39.

Punt, M. M., Raghavan, G. S. V., Belanger, J. M. R., \& Pare, J. R. J. (1999). Microwave-assisted process (MAPTM) for the extraction of contaminants from soil. Journal of Soil Contamination, 8(5), 577-592.

Rabinovich, M. L., Bolobova, A. V. \& Vasil'chenko, L. G. (2004). Decomposition of natural aromatic structures and xenobiotics by fungi. Prikladnaia biokhimiia i mikrobiologiia, 40(1): 5-23.

Raviv, M., Medina, S., Krasnovsky, A., \& Ziadna, H. (2004). Organic matter and nitrogen conservation in manure compost for organic agriculture. Compost Science \& Utilization, 12(1): 6-10.

Rhodes, C. J. (2014). Mycoremediation (bioremediation with fungi) - growing mushrooms to clean the earth. Chemical Speciation \& Biology, 26(3):196-198.

Rigi, K. (2018). Effect of seed priming on some physiological and agronomic characteristics of sunflower varieties (Doctoral dissertation, University of Zabol).

Robichaud, K., Girard, C., Dagher, D., Stewart, K., Labrecque, M., Hijri, M., \& Amyot, M. (2019). Local fungi, willow and municipal compost effectively remediate petroleum-contaminated soil in the Canadian North. Chemosphere, 220: 47-55. 
Robinson, B. H., Leblanc, M., Petit, D., Brooks, R. R., Kirkman, J. H., \& Gregg, P. E. (1998). The potential of Thlaspi caerulescens for phytoremediation of contaminated soils. Plant and Soil, 203(1), 47-56.

Royse, D. (2002). Influence of spawn rate and commercial delayed release nutrient levels on Pleurotus cornucopiae (oyster mushroom) yield, size, and time to production. Applied Microbiology and Biotechnology, 58(4), 527-531.

Santiago-Urbina, J. A., \& Ruíz-Terán, F. (2014). Microbiology and biochemistry of traditional palm wine produced around the world. International Food Research Journal, 21(4)ngh, A., \& Singh, A. and Gauba, P. (2014). Mycoremediation: a treatment for heavy metal pollution of soil. Journal of Civil Engineering and Environmental Technology, 1, 59-61.

Sarkar, D., Ferguson, M., Datta, R., \& Birnbaum, S. (2005). Bioremediation of petroleum hydrocarbons in contaminated soils: comparison of biosolids addition, carbon supplementation, and monitored natural attenuation. Environmental pollution, 136(1), 187195.

Stamets, P. (2005). Mycelium running: how mushrooms can help save the world. Random House, Inc. pp. 83-84.

Stjerndahl, M., Lundberg, D., Chauhan, V., Bordes, R., \& Holmberg, K. (2019). Cleavable Surfactants: A Comparison between Ester, Amide, and Carbonate as the Weak Bond. Journal of Surfactants and Detergents.

Taylor, P. G., \& Townsend, A. R. (2010). Stoichiometric control of organic carbon-nitrate relationships from soils to the sea. Nature, 464(7292): 1178.

Tisdale, S. L., \& Nelson, W. L. (1958). Soil fertility and fertilizers. Macmillan Company.; New York.

USEPA 350M/3550 (2014). Microwave assisted extraction. U.S. Environmental Protection Agency, Office of Research and Development, Washington, DC.

USEPA 3546. Microwave assisted extraction. U.S. Environmental Protection Agency, Office of Research and Development, Washington, DC

USEPA METHOD -846 Test Method 8270E: Semivolatile Organic Compounds by Gas Chromatography/Mass Spectrometry (GC/MS). U.S. Environmental Protection Agency, Office of Research and Development, Washington, DC.

USEPA SSOP(2014). Soil Sampling Operating Procedures. SESDPROC-300-R3:1-24. U.S. Environmental Protection Agency, Office of Research and Development, Washington, DC.

Van, T. C., Ramirez, J., Rainey, T., Ristovski, Z., \& Brown, R. J. (2019). Global impacts of recent IMO regulations on marine fuel oil refining processes and ship emissions. Transportation Research Part D: Transport and Environment, 70: 123-134. 
Wang, L., Yang, M., Fan, X., Zhu, X., Xu, T. and Yuan, Q. (2011). An environmentally friendly and efficient method for xylitol bioconversion with high-temperature-steaming corncob hydrolysate by adapted Candida tropicalis. Process Biochemistry, 46(8): 1619-1626.

Weber, F., \& Passon, M. (2019). Characterization and quantification of polyphenols in fruits. In Polyphenols in Plants (pp. 111-121). Academic Press.

Whalen, J. K., Chang, C., Clayton, G. W., \& Carefoot, J. P. (2000). Cattle manure amendments can increase the $\mathrm{pH}$ of acid soils. Soil Science Society of America Journal, 64(3): 962-966.

Whitehead, D. L. and Quicke, G. V. (1964). A comparison of six methods of estimating lignin in grass hay. Journal of the Science of Food and Agriculture, 15(6): 417-422.

Winquist, E., Björklöf, K., Schultz, E., Räsänen, M., Salonen, K., Anasonye, F., Cajthaml, T., Steffen, K.T., Jørgensen, K.S., Tuomela, M. (2014). Bioremediation of PAH-contaminated soil with fungi-from laboratory to field scale. International Biodeterioration \& Biodegradation, 86: 238- 247.

Xing, X., Qi, S., Zhang, J., Wu, C., Zhang, Y., Yang, D., \& Odhiambo, J. O. (2011). Spatial distribution and source diagnosis of polycyclic aromatic hydrocarbons in soils from Chengdu Economic Region, Sichuan Province, western China.Journal of Geochemical Exploration, 110(2): 146-154.

Yabi, I., \& Afouda, F. (2012). Extreme rainfall years in Benin (West Africa). Quaternary International, 262, 39-43.

Yang, X., Yuan, X., Zhang, A., Mao, Y., Li, Q., Zong, H., ... \& Li, X. (2015). Spatial distribution and sources of heavy metals and petroleum hydrocarbon in the sand flats of Shuangtaizi Estuary, Bohai Sea of China. Marine Pollution Bulletin, 95(1): 503- 512.

Zheng, Y., Li, J., Cao, W., Liu, X., Jiang, F., Ding, J., ... \& Sun, C. (2019). Distribution characteristics of microplastics in the seawater and sediment: A case study in Jiaozhou Bay, China. Science of The Total Environment. 674: 27-35. 